\title{
Removal of Chromium (VI) from Tannery Effluent Using Bio-Char of Phoenix reclinata Seeds
}

\author{
Joseph Katenta1,2, Caroline Nakiguli1 ${ }^{1}$ Paul Mukasa1, Emmanuel Ntambi ${ }^{{ }^{*}}$ \\ ${ }^{1}$ Department of Chemistry, Faculty of Science, Mbarara University of Science \& Technology, Mbarara, Uganda \\ ${ }^{2}$ Trinity College Nabbingo, Kampala, Uganda \\ Email: ^emmantambi@must.ac.ug
}

How to cite this paper: Katenta, J., Nakiguli, C., Mukasa, P. and Ntambi, E. (2020) Removal of Chromium (VI) from Tannery Effluent Using Bio-Char of Phoenix reclinata Seeds. Green and Sustainable Chemistry, 10, 91-107.

https://doi.org/10.4236/gsc.2020.103007

Received: July 24, 2020

Accepted: August 25, 2020

Published: August 28, 2020

Copyright $\odot 2020$ by author(s) and Scientific Research Publishing Inc. This work is licensed under the Creative Commons Attribution International License (CC BY 4.0).

http://creativecommons.org/licenses/by/4.0/

\begin{abstract}
The potential of the Senegal date palm (Phoenix reclinata) seed bio-char to remove chromium (VI) ions from aqueous solutions by adsorption was investigated. Adsorption experiments were performed on the tannery effluent and standard aqueous solutions of chromium (VI) for varying adsorbent doses, contact times, $\mathrm{pH}$, temperatures, and interfering anionic ions by batch mode. Phoenix reclinata seeds (PRS) bio-char was used in the investigation and the residual chromium (VI) was determined using the atomic absorption spectrophotometer (AAS). Results showed that the bio-char removed up to $86 \%$ of chromium (VI) ions in the effluent at $\mathrm{pH} 2$. The highest percentage adsorption registered was $97 \%$ in an aqueous solution of chromium (VI) at $\mathrm{pH} 1$ and this dropped to less than $10 \%$ at $\mathrm{pH}$ greater than 2 . A general increase in adsorption with the increase in temperature was observed but reduced when the temperature was raised beyond $60^{\circ} \mathrm{C}$. The presence of interfering anions caused a reduction in the adsorption of chromium (VI) ions. The adsorption process fitted both Langmuir and Freundlich adsorption models and the maximum adsorption capacity, $Q_{o}$, was $0.6593 \mathrm{mg} / \mathrm{g}$. Thus, PRS bio-char can therefore be used by industries and institutions like secondary schools to treat effluents that contain chromium (VI).
\end{abstract}

\section{Keywords}

Phoenix reclinata, Chromium (VI), Tannery Effluent, Adsorption

\section{Introduction}

Chromium is one of the top sixteen most toxic pollutants and because of its carcinogenic and teratogenic characteristics, it has become a serious health concern 
[1]. There are two stable oxidation states of chromium, that is, chromium (III) and chromium (VI). Whereas chromium (III) is essential in human nutrition (especially in glucose metabolism), most of the chromium (VI) compounds are toxic and can cause lung cancer [2]. There are many industries in Uganda that use chromium compounds as raw materials and then release the wastes into the environment. Among such industries include leather tanning, textiles, cement mining, electroplating, photography, paint manufacturing and fertilizer production [3]. There is a swift growth of such industries in Uganda due to the increasing demand for their finished products. Most of the industries do not have adequate treatment facilities for wastes and therefore, channel untreated or partially treated effluents into nearby water bodies [4].

Tannery effluent is of great concern in waste water management since it is laden with heavy metals, mainly chromium in form of chromium (VI) and chromium (III) [5]. The major source of the chromium in tannery effluent is the chromium sulphate (chrome) used as the tanning agent [4]. In Uganda, many if not all, small-scale tanning industries in urban and peri-urban areas cannot afford the expensive conventional methods of waste water treatment such as precipitation and ion exchange [6]. Those that use such methods cannot completely remove the toxic heavy metals from the effluent. Further to note is that most conventional methods used have inadequate efficiencies at low metal concentrations, particularly in the range of $1-100 \mathrm{mg} / 1$ [7]. The end result is that industries channel untreated or partially treated effluents with chromium and other heavy metals into the neighbouring water bodies or deposit precipitated chromium into landfills from where it leaches into groundwater in rainy seasons. It becomes necessary therefore, to find an environmentally friendly and inexpensive method of removing toxic heavy metals like chromium from tannery effluent before it is released to the environment.

The use of biological materials to adsorb metal ions is at its infancy but it is a good alternative measure since it is inexpensive and can efficiently remove metal ions from solutions with concentrations as low as $1 \mathrm{mg} / \mathrm{l}$ [7]. This study, therefore, investigated the potential of Phoenix reclinata seeds (PRS) bio-char to remove chromium (VI) from tannery effluent and standard aqueous solutions at different conditions.

\section{Materials and Methods}

\subsection{Collection and Preparation of Materials}

The adsorbates were: 1) the tannery effluent obtained from a tannery at Kijjabwemi, Masaka Municipality in Masaka District, Uganda in January 2018, at the point where the waste water enters Namajuzi swamp. The effluent was analysed at the Government Analytical Laboratories at Wandegeya and 2) the standard aqueous solution of chromium (VI), which was prepared by dissolving analytical grade potassium dichromate $(0.283 \mathrm{~g})$ in a litre of double distilled water to form a stock solution of $100 \mathrm{mg} / \mathrm{l}$ chromium (VI) ions. This stock solution was diluted appro- 
priately to provide solutions of different concentrations as used in the study [8].

Ripe fruits of Phoenix reclinata were collected by hand picking from the palm trees in Lweera wetland, Kalungu District, Uganda and sealed in a sample bag then transported to the Chemistry laboratory at Mbarara University of Science and Technology at ordinary conditions for further preparations. The seeds were dried under the sun for two weeks, and the fruit coat was removed. The bio-char was obtained by roasting the dry seeds in an oven at $220^{\circ} \mathrm{C}$ until they were black and easy to grind. An electric blender (model LBC15) was used to grind the seeds into powder, sieved using a plastic mesh $(710 \mu \mathrm{m})[8]$, to obtain the particle size of the PRS bio-char for the study.

\subsection{Parameters of the Effluent}

The $\mathrm{pH}$, biological oxygen demand (BOD), colour and chemical oxygen demand (COD) of the effluent were determined as per American Public Health Association (APHA) [9]. The concentrations of the heavy metals (chromium, lead, nickel, zinc copper and cadmium) in the effluent were determined by first diluting the effluent $(10 \mathrm{ml})$ with double distilled water to a litre. Then three samples of the diluted effluent $(5 \mathrm{ml})$ were used to determine the total concentration of each of the heavy metals by flame atomic absorption spectrophotometer (AAS) (model Agilent 200 series) at their respective wavelengths [10]. The concentration of chromium (VI) in the effluent was determined by the standard calorimetric method using 1,5-diphenycarbazide in an acid medium [9]. The concentration of chloride, sulphate and nitrate ions were determined by Volhard's [11], lead nitrate [12] and ferrous ions [13] titration methods respectively.

\subsection{Batch Adsorption}

Adsorption studies were conducted in triplicate by using the batch technique on both the tannery effluent and standard aqueous solution of $5.0 \mathrm{~g} / \mathrm{l}$ potassium dichromate so as to establish the adsorption of chromium (VI) ions onto the PRS bio-char adsorbent [14]. The adsorption factors studied on the tannery effluent were varying; adsorbent dosage, contact time and $\mathrm{pH}$. Other additional factors of varying temperature, chromium (VI) concentration and salinity were also studied when the standard aqueous chromium (VI) solution was used.

\subsubsection{Adsorption of Chromium (VI) from the Effluent}

To investigate the effect of adsorbent dosage, all other factors were kept constant and the amount of PRS bio-char used was varied. Briefly, $0.5 \mathrm{~g}$ PRS bio-char was added to each of the three $250 \mathrm{ml}$ conical flasks containing $100 \mathrm{ml}$ effluent at $25^{\circ} \mathrm{C}$. The flasks were corked and placed on an end-to-end shaker agitated for one hour at $250 \mathrm{rpm}$. The mixture was then filtered using a Whatmann 42 filter paper. The filtrates obtained were filled into three different sample bottles and the residual chromium in each was determined using AAS. The total chromium remaining in the effluent after adsorption was recorded as the average residual chromium (VI). The difference between the chromium concentration before $\left(C_{0}\right)$ and after treat- 
ment with the bio-char $\left(\mathrm{C}_{\mathrm{e}}\right)$ was determined as the amount of chromium (VI) adsorbed by the bio-char. Percentage adsorption $\left(A_{e q}\right)$ and adsorption capacity $\left(Q_{e}\right)$ at equilibrium were determined using Equations (1) and (2) respectively [15].

$$
\begin{aligned}
A_{e q} & =\frac{C_{o}-C_{e}}{C_{o}} \times 100 \\
Q_{e} & =\frac{V\left(C_{o}-C_{e}\right)}{W}
\end{aligned}
$$

$\mathrm{V}$ is the volume of solution and $\mathrm{W}$ is the amount or mass of the adsorbent.

The procedure was repeated using different masses $(0.8,1.0,1.5,2.0$ and 3.0) $\mathrm{g}$ of the bio-char.

The effect of varying contact time $(10,20,40,60,80,100$ and 120) minutes on the adsorption of chromium (VI) from the effluent was investigated at $25^{\circ} \mathrm{C}$ [2], $2.0 \mathrm{~g}$ adsorbent dosage, and $100 \mathrm{ml}$ effluent was used. The difference between the chromium concentration in the effluent before and after treating the mixture with bio-char was determined to give the amount of chromium (VI) adsorbed, the $A_{e q}$ and $Q_{e}$ [15].

The same experiments above were repeated using another sample of the same effluent but adjusting its $\mathrm{pH}$ to 2 with dilute sulphuric acid $(0.1 \mathrm{M})$. In both cases, the adsorption percentage and adsorption capacity were determined [15].

\subsubsection{Adsorption of Chromium (VI) from Aqueous Potassium Dichromate Solution}

To ascertain the efficiency of PRS bio-char in adsorption of chromium (VI) from a medium, a standard aqueous solution of chromium (VI) of $5.0 \mathrm{mg} / \mathrm{l}$ was prepared. The effect of various parameters on the adsorption of chromium (VI) from the standard solution was studied by keeping all other factors constant and varying the studied factor of adsorbent concentration, contact time, temperature, $\mathrm{pH}$, chromium (VI) concentration and salinity. While studying other factors, the $\mathrm{pH}$ was fixed at 2 since most studies have showed that it is the optimum $\mathrm{pH}$ for the adsorption of chromium (VI) on the binding sites of natural adsorbents at $25^{\circ} \mathrm{C}[2][8][16]$.

The effect of factors on the adsorption of chromium (VI) from $100 \mathrm{ml}$ of the standard aqueous chromium (VI) solution were varied as follows: adsorbent dosage $(0.5,0.8,1.0,1.5,2.0$ and 3.0) g, contact time $(10,20,40,60,80,100$ and 120) minutes, chromium (VI) ion concentration $(5,10,15$ and 20$) \mathrm{mg} / \mathrm{l}$, temperature $\left(25^{\circ} \mathrm{C}, 30^{\circ} \mathrm{C}, 40^{\circ} \mathrm{C}, 50^{\circ} \mathrm{C}, 60^{\circ} \mathrm{C}\right.$, and $\left.70^{\circ} \mathrm{C}\right), \mathrm{pH}(1,2,3,4,5,6,7,8,9$ and 10), and salinity for nitrate and chloride ions (0, 5.0, 10 and 20) $\mathrm{mg} / \mathrm{l}$. Where adsorbent dose was not the factor under study, $2.0 \mathrm{~g}$ of PRS bio-char was used. This is because it was the optimum adsorption mass established from this study in one hour contact time. Sulphuric acid $(0.1 \mathrm{M})$ and sodium hydroxide $(0.1 \mathrm{M})$ was used to adjust the $\mathrm{pH}$ of the standard aqueous solutions to the required value. In all treatments, the average residual chromium (VI) was calculated; hence $A_{e q}$ and $Q_{e}$ were determined [2] [8] [15]. 


\section{Results and Discussion}

\subsection{Parameters of the Effluent}

The average values of the parameters determined in the effluent are as shown in Table 1.

The effluent studied did not fully meet the national standards for industrial effluents disposal set by the Uganda National Environment Management Authority (NEMA) [17]. The parameters that did not meet the set standards were $\mathrm{pH}, \mathrm{Cr}, \mathrm{Pb}, \mathrm{BOD}$, and COD, Table 1 . The $\mathrm{pH}$ of the effluent was found to be 9 , indicating that the effluent is slightly alkaline. The effluent had much higher concentrations of both total chromium $(12.3 \pm 0.006 \mathrm{mg} / \mathrm{l})$ and chromium (VI) $(5.17 \pm 0.05) \mathrm{mg} / \mathrm{l}$ than the recommended discharge limits, 1.0 and $0.05 \mathrm{mg} / \mathrm{l}$, for industrial effluents [17] respectively. This shows that the effluent from the tannery causes accumulation of toxic chromium (VI) in the environment. Thus, the people who obtain water from Nabajjuzi swamp for use are likely to be exposed to chromium poisoning which may cause health hazards like lung cancer and abnormal formation of embryos [1]. The high values of BOD $(536 \pm 4.5) \mathrm{mg} / \mathrm{l}$ and COD $(772 \pm 5.0) \mathrm{mg} / \mathrm{l}$ in the effluent indicated a high demand for oxygen by the microorganisms for the oxidation of chemical substances in the effluent respectively. This leads to depletion of oxygen in the water of Nabajjuzi swamp into which the effluent is discharged and this eventually leads to suffocation of aquatic living organisms [18]. The concentration of lead $(0.66 \pm 0.01 \mathrm{mg} / \mathrm{l})$ was over six times above the limit Table 1 [17]. The effluent therefore introduces to the environment much lead which is known to be toxic to humans and is a priority pollutant observed in municipalities [19]. The concentration of nitrate $(59.7 \pm 1.2 \mathrm{mg} / \mathrm{l})$ was higher than the recommended limit of $20 \mathrm{mg} / \mathrm{l}$,

Table 1. Parameters of effluent from Novelty Tannery Factory at Kijjabwemi, Masaka (Units where applicable is $(\mathrm{mg} / \mathrm{l})$ ).

\begin{tabular}{ccc}
\hline Parameter & Quantity & Permissible limits [17] \\
\hline pH & 9.0 & $6-8.0$ \\
Colour (PtCo units) & $492.0 \pm 4.5$ & 300.0 \\
$\mathrm{BOD}$ & $536.0 \pm 4.5$ & 50.0 \\
$\mathrm{COD}$ & $772.0 \pm 5.0$ & 100.0 \\
$\mathrm{Cl}^{-}$ & $245.0 \pm 3.0$ & 500.0 \\
$\mathrm{NO}_{3}^{-}$ & $59.7 \pm 1.2$ & 20.0 \\
$\mathrm{SO}_{4}^{2-}$ & $101.30 \pm 1.4$ & 500.0 \\
$\mathrm{Cr}(\mathrm{total})$ & $12.3 \pm 0.01$ & 1.0 \\
$\mathrm{Cr}(\mathrm{VI})$ & $5.17 \pm 0.05$ & 0.05 \\
$\mathrm{~Pb}$ & $0.66 \pm 0.01$ & 0.1 \\
$\mathrm{Ni}$ & $0.29 \pm 0.01$ & 1.0 \\
$\mathrm{Zn}$ & $0.50 \pm 0.01$ & 5.0 \\
$\mathrm{Cu}$ & $0.17 \pm 0.003$ & 1.0 \\
$\mathrm{Cd}$ & $0.07 \pm 0,002$ & 0.10 \\
\hline
\end{tabular}


which could eventually lead to eutrophication that depletes the water of oxygen upon dying and decomposition of organic matter, causing the death of other aerobic organisms [18].

\subsection{Effect of Adsorbent Dosage}

There was a general increase in adsorption percentage with increase in adsorbent dose for both standard aqueous chromium (VI) solution and the effluent at $\mathrm{pH}$ 2, Figure 1 and Figure 2 respectively. This was attributed to the increased probability of the chromium (VI) ions getting into contact with the available active sites of the bio-char which increases with increase in the amount of adsorbent [2].

However, the adsorption capacity decreased with increase in adsorbent dose for the standard aqueous chromium (VI) solution as in Figure 1. This is because adsorption capacity is inversely proportional to adsorbent dosage level [8]. Increase in the amount of adsorbent, increases the available active sites for the uptake of chromium (VI) ions, but, if the concentration of its ions remains constant, the maximum holding capacity of a given active site may not be reached since many active sites are available to take up the few chromium (VI)

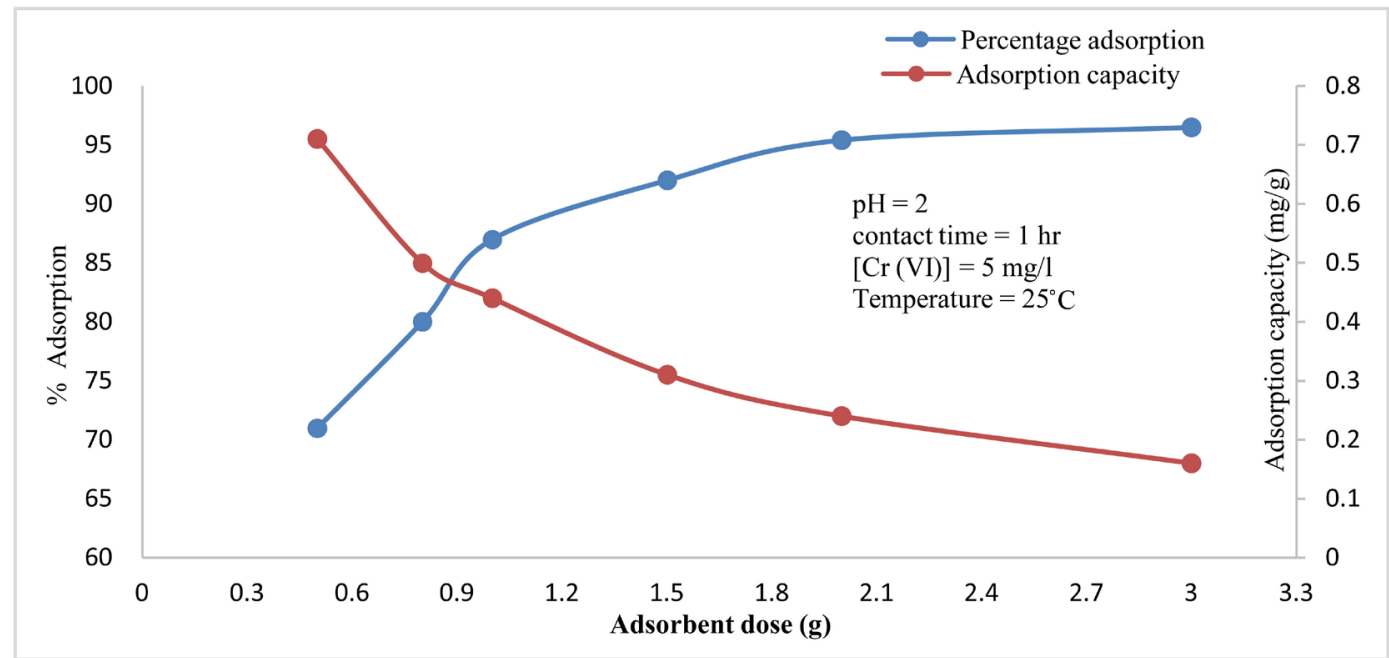

Figure 1. Effect of adsorbent dosage on percentage adsorption and adsorption capacity of chromium (VI) from the standard aqueous chromium (VI) solution.

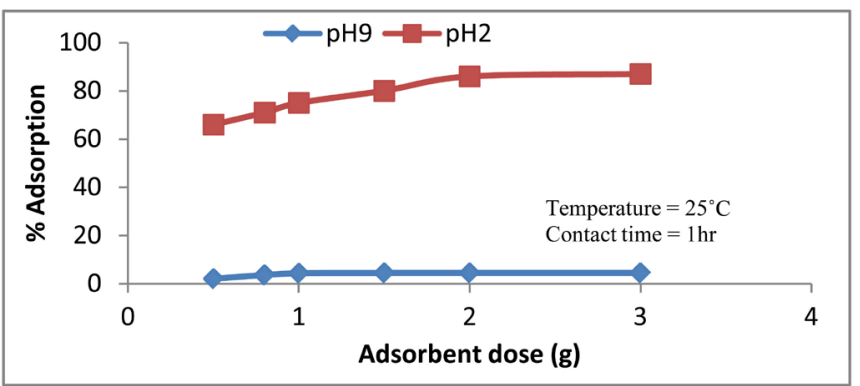

Figure 2. Effect of adsorbent dosage on percentage adsorption of chromium (VI) from the effluent at $\mathrm{pH} 9$ and 2. 
ions in that solution,leading to a decrease in the holding capacity (adsorption capacity) as observed.

At $\mathrm{pH}$ 9, the highest chromium (VI) adsorption percentage from the tannery effluent was $4.5 \%$ and this was attributed to the alkaline nature of the effluent. In alkaline systems the protonation of the active sites decreases, lowering the magnitude of the positive charge on the adsorbent sites [8], thus the attraction of the anionic chromium (VI) ions reduces. When the $\mathrm{pH}$ of the effluent was adjusted to 2 , adsorption percentage was raised to $87 \%$. The high adsorption percentage at $\mathrm{pH} 2$ agrees with the work of [2] [8], who found out that adsorbents of plant origin have an optimum working $\mathrm{pH}$ of 2 . This behaviour was attributed to the fact that in strongly acidic solutions, the functional groups on the adsorbent surface become positively charged due to protonation by many hydrogen ions in the acidic solution which enables the high attraction of chromium (VI) ions that exist at $\mathrm{pH} 2$ predominantly as $\mathrm{HCrO}_{4}^{-}$[2]. The adsorption percentage from the effluent (87\%) was less than that for the standard aqueous chromium (VI) solution (95.7\%) under the same conditions. This is because the effluent contained anionic species like $\mathrm{Cl}^{-}, \mathrm{NO}_{3}^{-}$and $\mathrm{SO}_{4}^{2-}$ which may have interfered or competed with the chromium (VI) ions for adsorption surfaces onto the same positively charged active sites on the PRS bio-char particles.

\subsection{Effect of Contact Time}

The trend observed for the adsorption percentage of chromium (VI) from the standard aqueous solution and the effluent at $\mathrm{pH} 2$ and $\mathrm{pH} 9$ is illustrated in Figure 3. The adsorption percentage of chromium (VI) generally increased with increase in contact time. At $\mathrm{pH} \mathrm{2,} \mathrm{the} \mathrm{increase} \mathrm{in} \mathrm{adsorption} \mathrm{percentage} \mathrm{was}$ slightly more for standard aqueous solution than for the effluent. The highest adsorption percentage was $96.1 \%$ for the standard aqueous chromium (VI) solution and the lowest adsorption observed was $4.6 \%$ for the effluent. The increase in percentage removal of chromium (VI) at $\mathrm{pH} 2$ was attributed to increased

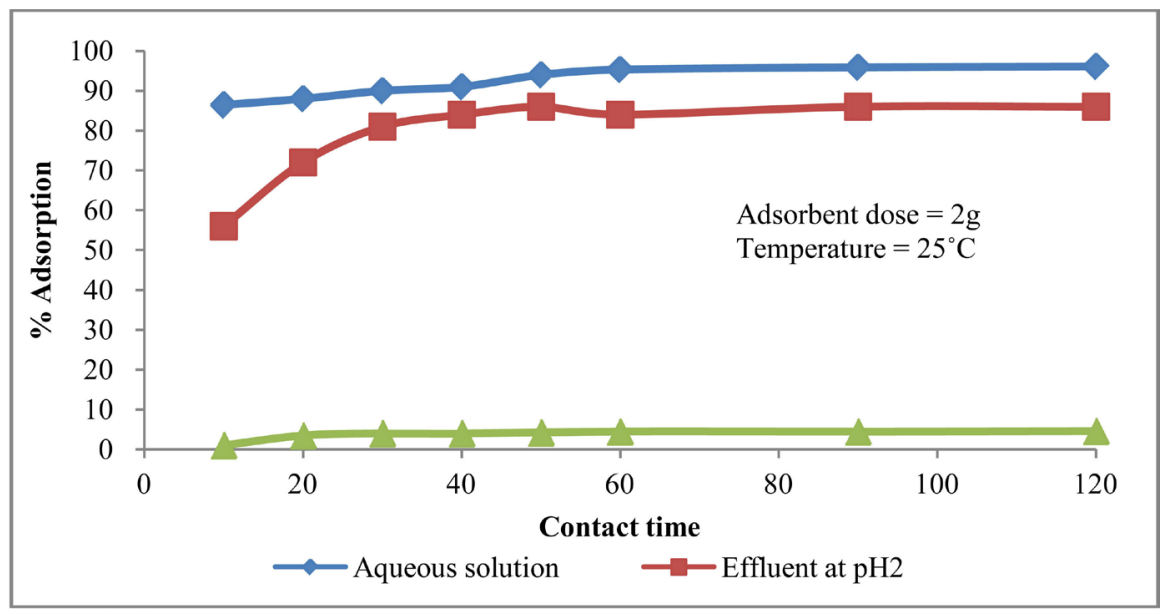

Figure 3. Effect of contact time on percentage adsorption of chromium (VI) from the effluent and standard aqueous chromium (VI) solution by PRS biochar at $\mathrm{pH} 2$ and $\mathrm{pH} 9$. 
contact time allowed for the interaction of the chromium (VI) ions with the active sites on the bio-char. The initial rapid increase in adsorption percentage up to 30 minutes was due to the availability of many free active sites on the adsorbent surface. The gradual increase in adsorption after one hour was due to the reduced probability of the incoming $\mathrm{HCrO}_{4}^{-}$containing chromium (VI) ions to find free active sites and also due to the electrostatic repulsion between the incoming ions by the already adsorbed ions [8]. The low percentage removal of chromium (VI) from the tannery effluent at $\mathrm{pH} 9$ was due to its alkaline nature which hinders adsorption to occur.

Adsorption capacity of the bio-char for both the standard aqueous chromium (VI) solution and the effluent at $\mathrm{pH} 2$ increased with increase in contact time as in Figure 4. This was due to the longer time allowed for the bio-char to interact with the chromium (VI) ions leading to greater amount of ions to be adsorbed per unit mass of the bio-char, hence higher adsorption capacity [8].

\subsection{Effect of $\mathrm{pH}$}

At low $\mathrm{pH}$ values, the adsorption of chromium (VI) by PRS bio-char is extremely higher than that at high $\mathrm{pH}$ values as shown in Figure 5 from aqueous solution.

The highest adsorption percentage (97\%) was at $\mathrm{pH} 1$, and an increase in $\mathrm{pH}$ beyond 2 resulted into a rapid decrease in both adsorption percentage and adsorption capacity. This may be attributed to the fact that at $\mathrm{pH} 2$ and below, the dominant species in the solution is hydrogen chromate ions $\left(\mathrm{HCrO}_{4}^{-}\right)$and at such low $\mathrm{pH}$, the concentration of protons in the solution is high [2], which causes the active sites of the adsorbent (PRS bio-char) to become positively charged due to protonation of the functional groups which may be amines and carboxyl in nature [8]. This promotes the electrostatic attraction for the $\mathrm{HCrO}_{4}^{-}$ ions since they are negatively charged. The protonation of the active sites decreases as the $\mathrm{pH}$ increases and thus, the attraction of the anionic chromium (VI) ions decreases due to reduction in the magnitude of the positive charge on

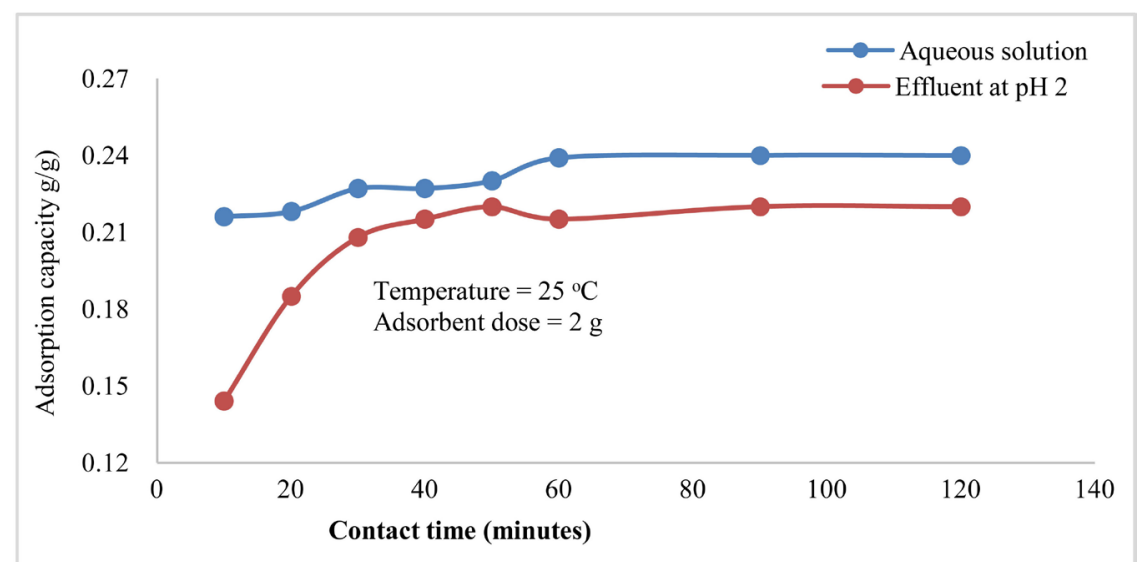

Figure 4. Effect of contact time on chromium (VI) adsorption capacity by PRS bio-char from the effluent at $\mathrm{pH} 2$ and the standard aqueous chromium (VI) solution. 
the adsorbent. These findings agree with the results reported in [2] [8] [16], which found out that the suitable $\mathrm{pH}$ for the adsorption of chromium (VI) species by plant materials is 2 and below.

\subsection{Effect of Temperature}

The percentage adsorption and adsorption capacity of chromium (VI) from the standard aqueous solution increased with temperature up to $60^{\circ} \mathrm{C}$, beyond which it decreased as in Figure 6. This is because increase in temperature provides the necessary energy required for the endothermic adsorption process of the ions during migration onto the active sites of the PRS bio-char [20]. The increase in temperature also increases the diffusion rate of the chromium (VI) ions in the solution. When the temperature exceeded $60^{\circ} \mathrm{C}$, the percentage adsorption decreased because increase in thermal energy at temperatures beyond

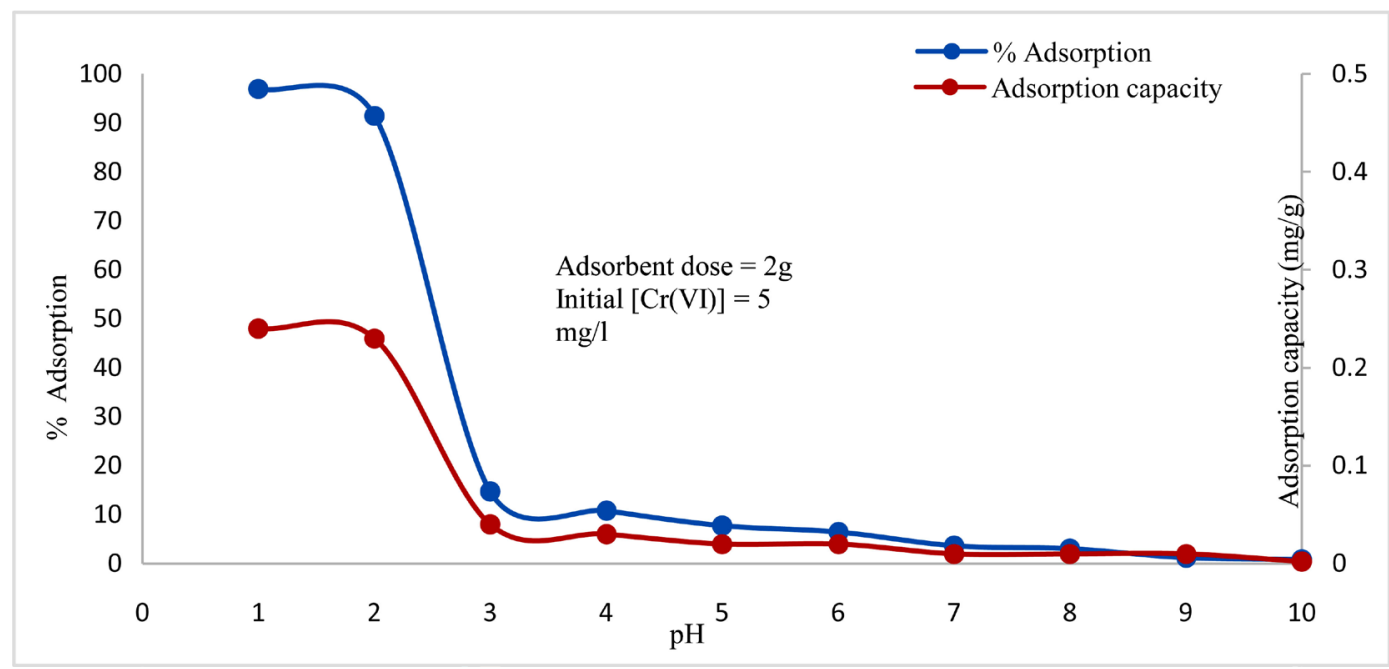

Figure 5. Effect of $\mathrm{pH}$ on percentage adsorption and adsorption capacity of chromium (VI) from standard aqueous solution.

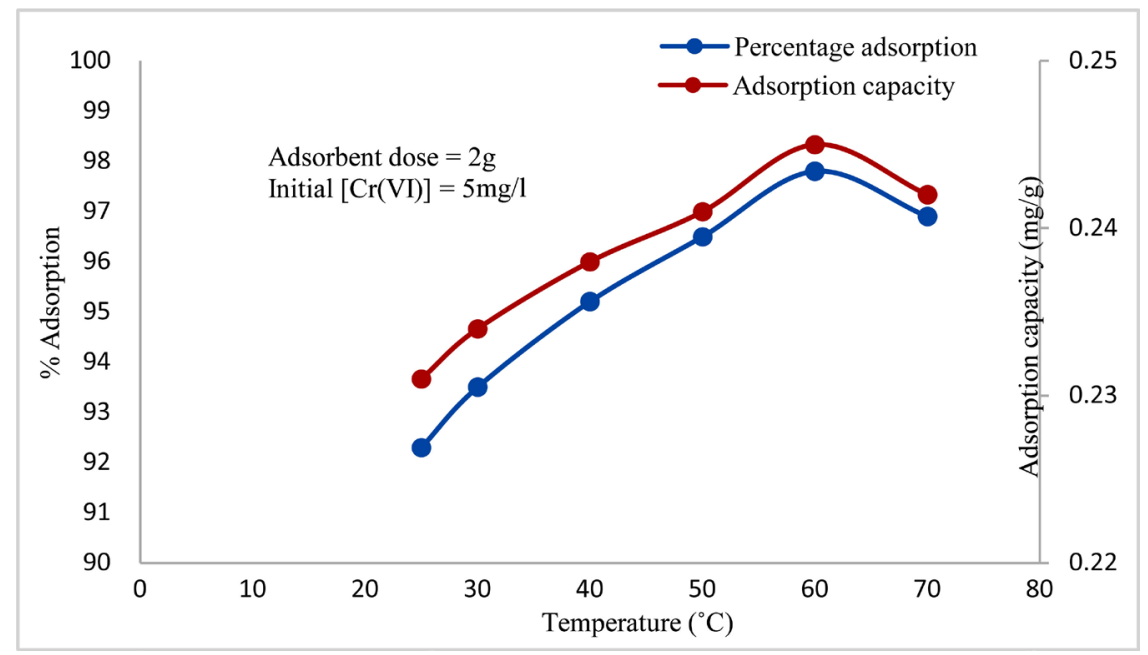

Figure 6. Effect of temperature on percentage adsorption and adsorption capacity of chromium (VI) from the standard aqueous solution. 
$60^{\circ} \mathrm{C}$ increases the mobility of the chromium (VI) ions in the solution to such a level that desorption rate is higher than adsorption rate [20]. The results of this study agree with [8] who reported that beyond $60^{\circ} \mathrm{C}$, the adsorption efficiency of the raw jackfruit seed powder reduced for chromium (VI) in aqueous solutions. From this study, therefore, the adsorption of chromium (VI) ions by PRS bio-char is most efficient at $60^{\circ} \mathrm{C}$, with $97.8 \%$ percentage removal from the aqueous solution with corresponding adsorption capacity of $0.245 \mathrm{mg} / \mathrm{g}$.

\subsection{Effect of Varying Chromium (VI) Concentration}

The adsorption efficiency of PRS bio-char decreased with increase in chromium (VI) concentration as given in Figure 7. As the concentration of chromium (VI) ions was increased, their competition for the PRS bio-char active sites increased, and the chance of the ions getting adsorbed decreased which in turn reduces the adsorption percentage [8]. However, increase in the chromium (VI) concentration increased the adsorption capacity (holding capacity of the bio-char) due to the increase in the availability of chromium (VI) ions on the interface which enhanced the degree of holding the chromium (VI) ions by the adsorbent [21].

\subsection{Effect of Salinity}

Salts that contain anionic species $\left(\mathrm{NO}_{3}^{-}, \mathrm{Cl}^{-}\right)$were introduced into the standard aqueous chromium (VI) solution at $\mathrm{pH} 2$, to observe their effect on the adsorption efficiency of chromium (VI) ions by the PRS bio-char. From Figure 8, it is observed that the introduction of nitrate ions $\left(\mathrm{NO}_{3}^{-}\right)$in solution decreased the percentage adsorption of chromium (VI) ions by PRS bio-char. Increase in the concentration of the nitrate ions in solution, decreased the adsorption efficiency of chromium (VI) by the bio-char. The same trend was observed with chloride ions $\left(\mathrm{Cl}^{-}\right)$. The observed trend is attributed to the fact that $\mathrm{NO}_{3}^{-}$and $\mathrm{Cl}^{-}$anions competed for the same positively charged active sites on the adsorbent with

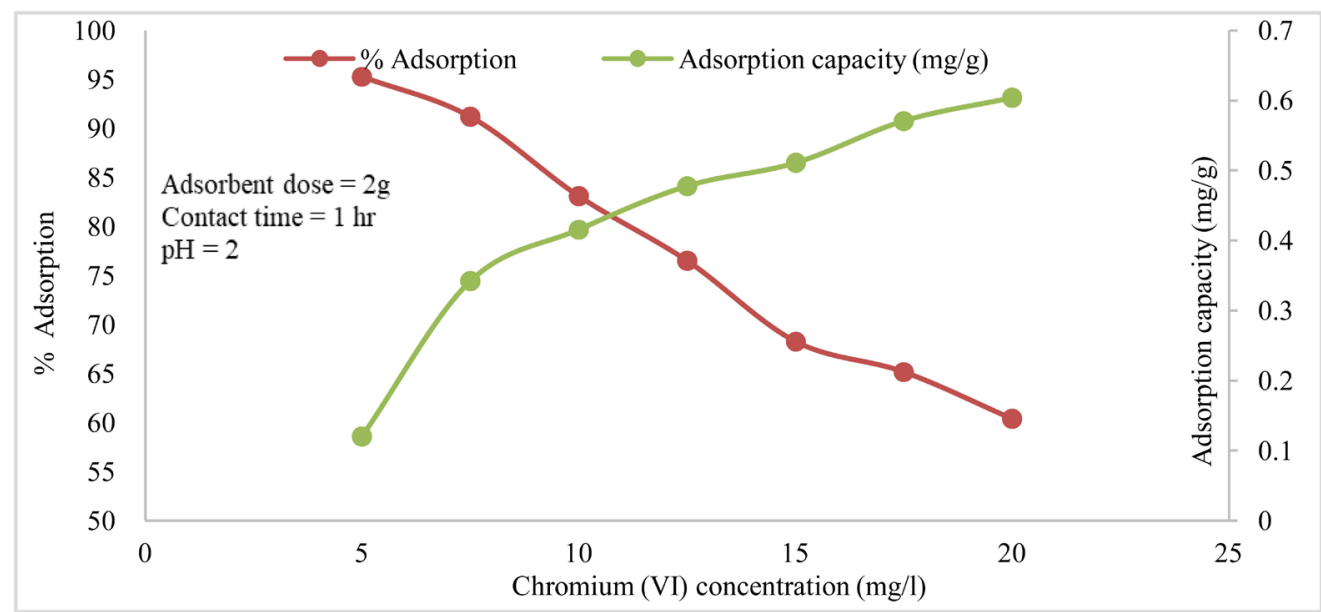

Figure 7. Effect of varying chromium (VI) ion concentration on percentage adsorption and adsorption capacity. 


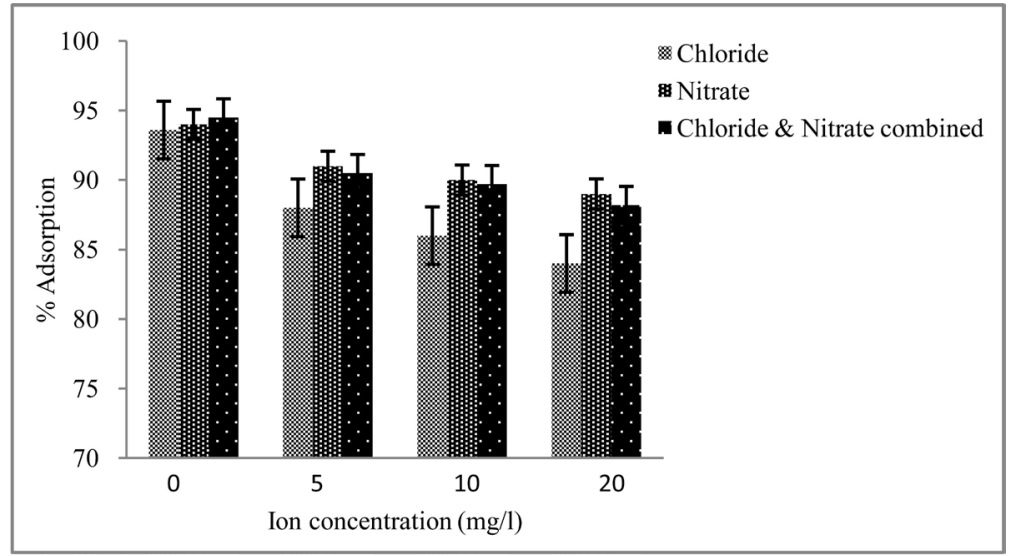

Figure 8. Effect of interfering anions on the adsorption of chromium (VI) from aqueous solution by PRS bio-char.

chromium(VI) ions, which at $\mathrm{pH} 2$ exist mainly as anionic hydrogen chromate ion $\left(\mathrm{HCrO}_{4}^{-}\right)$[8]. Since both $\mathrm{NO}_{3}^{-}$and $\mathrm{Cl}^{-}$ions are lighter than the $\mathrm{HCrO}_{4}^{-}$ions, they have a higher mobility in solution, hence get adsorbed onto the active sites much faster, which in turn reduced the percentage of $\mathrm{HCrO}_{4}^{-}$that gets adsorbed. The combined effect of chloride and nitrate ions on adsorption showed the same trend at any given concentration as with the individual ions. The decrease in adsorption caused by combining the two ions was less than the individual decrease caused by the chloride ions Figure 8 . This is explained by the fact that the combined average mass of the chloride and nitrate ions is higher than the mass of the individual chloride ion. Therefore, the average velocity of the two ions combined as they diffuse in solution is slower and hence, their competition with the chromium (VI) ions for adsorption at the active sites on the PRS bio-char surface is less than that caused by the same amount of individual chloride ions. Effect of $\mathrm{SO}_{4}^{2-}$ ions was not studied because sulphuric acid was used to adjust the $\mathrm{pH}$ to 2 during the study.

\subsection{Adsorption Thermodynamics}

The adsorption thermodynamic parameters were determined from the relations as described by [22]. The change in standard Gibbs free energy, $\Delta G^{o}$ and the equilibrium constant, $K_{\circ}$ were calculated from Equations (3) and (4) respectively. The standard enthalpy change, $\Delta H^{\circ}$ of $+27186.78 \mathrm{~J} / \mathrm{mol}$ and standard entropy change, $\Delta S^{o}$ of $+112.355 \mathrm{~J} / \mathrm{K} / \mathrm{mol}$, were obtained from the slope and intercept of the plot in Figure 9, respectively, using the linear Vant Hoff isotherm Equation (5).

$$
\begin{gathered}
\Delta G^{o}=-R T \ln K_{c} \\
K_{c}=\frac{C_{a d}}{C_{e q}} \\
\ln K_{c}=\frac{\Delta S^{o}}{R}-\frac{\Delta H^{o}}{R T}
\end{gathered}
$$




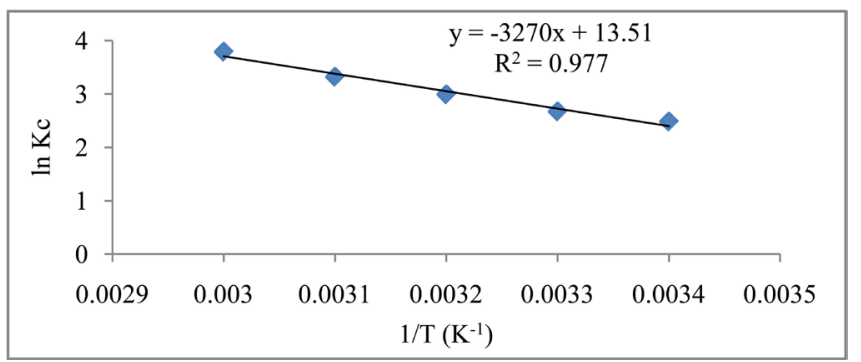

Figure 9. A plot of $\ln K_{c}$ against $1 / T$ for the determination of $\Delta H^{o}$ and $\Delta S^{o}$.

Table 2. Thermodynamic parameters for adsorption of chromium (VI) ions from aqueous solution by PRS bio-char.

\begin{tabular}{ccccccc}
\hline Temp K & $1 / T / \mathrm{K}$ & $K_{c}$ & $\ln K_{c}$ & $\Delta G^{o}(\mathrm{~J} / \mathrm{mol})$ & $\Delta H^{o}(\mathrm{~J} / \mathrm{mol})$ & $\Delta \mathcal{S}^{o}(\mathrm{~J} / \mathrm{K} / \mathrm{mol})$ \\
\hline 298 & 0.0034 & 11.987 & 2.48 & -6144.379 & & \\
303 & 0.0033 & 14.385 & 2.67 & -6726.109 & & \\
313 & 0.0032 & 19.833 & 2.99 & -7780.823 & $+27,186.78$ & +112.355 \\
323 & 0.0031 & 27.571 & 3.32 & -8915.601 & & \\
333 & 0.0030 & 44.455 & 3.79 & -10492.850 & & \\
\hline
\end{tabular}

where, $C_{a d}$ is concentration of chromium (VI) adsorbed, $C_{e q}$ is equilibrium chromium (VI), $R$ is the universal gas constant and $T$ is the temperature in Kelvin.

The values of $\Delta G^{o}$ obtained were negative as shown in Table 2 and the magnitude of these values increased within the temperature range investigated in this study. This indicates that the adsorption of chromium (VI) ions by PRS bio-char is feasible and it occurs spontaneously. Also, all the values of $\Delta G^{o}$ are above $41.86 \mathrm{~kJ} / \mathrm{mol}$, an indication that the adsorption is a chemical process, and the increasing magnitude of $\Delta G^{o}$ with temperature shows that the adsorption is favoured by increase in temperature [16]. The value of $\Delta H^{o}$ is positive showing that the adsorption process is endothermic [22], a sign that monolayer chemisorption occurred according to [20], which require absorption of some heat energy to overcome the energy barrier. The positive value of $\Delta S^{o}$ showed that the degree of disorder or randomness of the system increased with increase in temperature and it also indicates an increase in the affinity of the bio-char for chromium (VI) ions from the aqueous solution.

\subsection{Adsorption Isotherms}

The data was fitted to both the common linear Langmuir and Freundlich isotherm models as given in Equations (6) and (7) respectively. The Freundlich isotherm model is an empirical relationship used to describe the adsorption of solutes (chromium (VI) from a liquid to a solid surface (PRS bio-char), and assumes that different sites are available with several adsorption energies and allows for multilayer formation [23]. However, the Langmuir model is restricted to the uniformity of sites and only assumes monolayer capacity [24]. 


$$
\begin{gathered}
\frac{C_{e}}{Q_{e}}=\frac{1}{K_{L} Q_{o}}+\frac{C_{e}}{Q_{o}} \\
\log Q_{e}=\log K_{f}+\left(\frac{1}{n}\right) \log C_{e}
\end{gathered}
$$

where $K_{L}$ and $Q_{o}$ are Langmuir constants related to rate of adsorption and adsorption capacity respectively, $K_{f}$ and $n$ are Freundlich constants representing adsorption capacity or distribution coefficient and intensity of adsorption. The essential features of the Langmuir adsorption isotherm can be expressed in terms of a dimensionless constant, $R_{L}$, which is defined by the relationship in Equation (8).

$$
R_{L}=\frac{1}{1+K_{L} C_{o}}
$$

where $C_{o}$ is initial chromium (VI) concentration.

From the linear Langmuir adsorption isotherm as given by equation (6), a graph of $C_{e} / Q_{e}$ against $C_{e}$ was plotted and a straight line graph obtained as shown in Figure 10 with correlation coefficient of 0.9923 and a slope $1 / Q_{o}$. This linear plot was used to determine $Q_{o}$ and $K_{L}$. The slope obtained was 1.5168 from which $Q_{o}$ was found to be 0.6593 . Using the value of the intercept as 1.4788 , and $Q_{o}(0.6593), K_{L}$ was obtained as 1.0257 as given in Table 3 . The $R_{L}$ values were also obtained and these values lie between 0 and 1 , which shows that the adsorption is favourable and fits the Langmuir isotherm under the conditions of the study.

The linear Freundlich isotherm equation, as given in equation (7), was used to obtain the constants, $n$ (adsorption intensity) and $K_{f}$ (distribution coefficient). These were obtained by plotting $\log Q_{e}$ against $\log C_{e}$ as shown in Figure 11. This gave straight line with slope of $1 / n$, showing that the adsorption of chromium

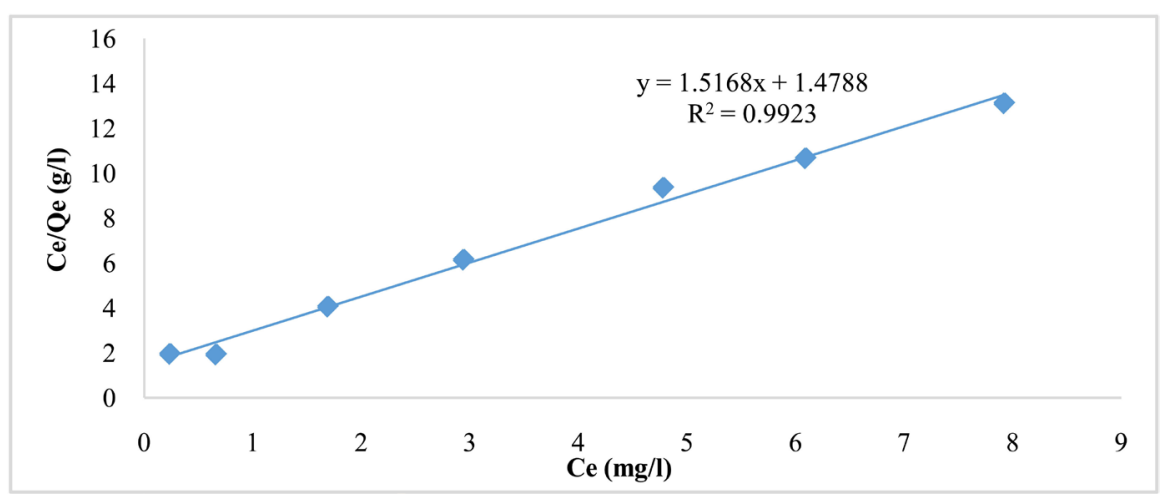

Figure 10. Langmuir isotherm for adsorption of chromium (VI) by PRS bio-char.

Table 3. $R_{L}$ values for adsorption of chromium (VI) from aqueous solution by PRS bio-char.

\begin{tabular}{cccccccc}
\hline$C_{o}=[\mathrm{Cr}(\mathrm{VI})](\mathrm{mg} / \mathrm{l})$ & 5.0 & 7.5 & 10.0 & 12.5 & 15.0 & 17.5 & 20 \\
$R_{L}$ & 0.1632 & 0.1150 & 0.0888 & 0.0724 & 0.0611 & 0.0528 & 0.0465 \\
\hline
\end{tabular}


(VI) follows the Freundlich model with correlation coefficient of $r^{2}=0.8699$. The $K_{f}$ and $n$ values were calculated to be 0.2909 and 2.4667 respectively as given in Table 4. The slope obtained, ranging between 0 and 1 , it is a measure of adsorption intensity or surface heterogeneity, and the surface becomes more heterogeneous as the value of $\mathrm{n}$ value gets closer to zero [25]. A comparison was made of PRS biochar against other adsorbents that have been used to remove chromium (VI) from aqueous solution. It can be observed that PRS biochar compare well with the other adsorbents listed in Table 5.

\section{Conclusion}

PRS bio-char demonstrated the ability to remove chromium (VI) from both the tannery effluent and the standard $\mathrm{Cr}(\mathrm{VI})$ aqueous solution, particularly at $\mathrm{pH} 2$

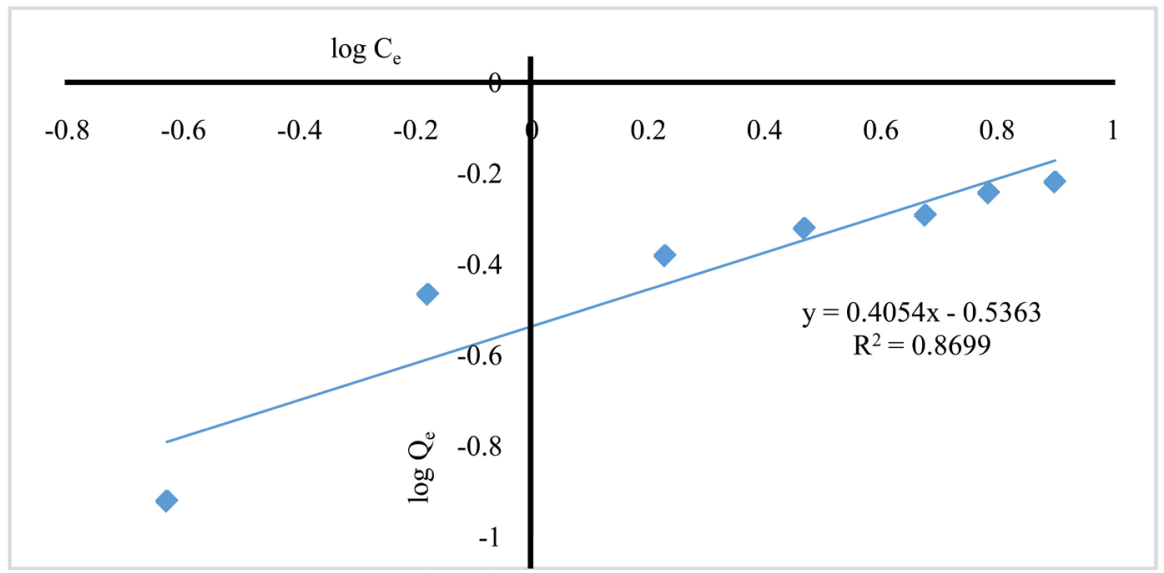

Figure 11. Freundlich isotherm for adsorption of chromium (VI) by PRS bio-char.

Table 4. Estimated isotherm parameters for chromium (VI) adsorption by PRS bio-char.

\begin{tabular}{ccc}
\hline Isotherm & $\mathbf{R}^{2}$ & Parameters \\
\hline Freundlich & 0.8686 & $K_{f}=0.2909$ \\
& & $n=2.4667$ \\
Langmuir & 0.9922 & $Q_{o}=0.6593 \mathrm{mg} / \mathrm{g}$ \\
& $K_{L}=1.0257 \mathrm{l} / \mathrm{mg}$ \\
& $R_{L}=0.0465-0.1632$ \\
\hline
\end{tabular}

Table 5. Comparison of adsorption capacity of PRS bio-char with other adsorbents.

\begin{tabular}{ccccc}
\hline Adsorbent & $Q_{o}(\mathrm{mg} / \mathrm{g})$ & $\mathrm{pH}$ & $C_{o}$ & Reference \\
\hline Activated rice husk carbon & 0.80 & 2 & 10 & {$[26]$} \\
Activated alumina & 1.60 & 4 & 5 & {$[26]$} \\
Raw rice bran & 0.07 & 2 & 5 & {$[27]$} \\
Wheat bran & 0.94 & 2 & 5 & {$[2]$} \\
Jackfruit seed powder & 0.57 & 2 & 5 & {$[8]$} \\
Phoenix reclinata seed bio-char & 0.66 & 2 & 5 & Present study \\
\hline
\end{tabular}


and below. For a solution containing $5 \mathrm{mg} / \mathrm{l}$ chromium (VI), to bring about effective adsorption, one would need to use $1.5 \mathrm{~g}$ of PRS bio-char powder on 100 $\mathrm{ml}$ of solution for one hour at $25^{\circ} \mathrm{C}$. The adsorption process of chromium (VI) onto PRS bio-char was spontaneous even at $25^{\circ} \mathrm{C}$ as given by the thermodynamic parameters and it was found to be endothermic. The data fitted the Langmuir model better than the Freundlich model with a high regression coefficient and thus can be used to describe and explain the adsorption of chromium (VI) on PRS bio-char. According to the Langmuir model, the maximum adsorption capacity, $Q_{o}$, of PRS bio-char powder was found to be $0.6593 \mathrm{mg}$ of chromium (VI) per gram of adsorbent. Therefore, the bio-char of Phoenix reclinata seeds can be used, for example, by ternaries and secondary schools to effectively remove chromium (VI) from aqueous systems under ordinary conditions at a low cost.

\section{Acknowledgements}

The authors wish to acknowledge the support from Mbarara University of Science and Technology, and the technical assistance rendered by the Laboratory of the Department of Geology and Petroleum studies, College of Natural Sciences, Makerere University.

\section{Conflicts of Interest}

The authors declare no conflicts of interest regarding the publication of this paper.

\section{References}

[1] Gardea-Torresdey, J.L., Tiemann, K.J. and Armendariz, V. (2000) Characterization of $\mathrm{Cr}(\mathrm{VI})$ Binding and Reduction to $\mathrm{Cr}$ (III) by Agricultural Byproducts of Avena monida (Oat) Biomass. Journal of Hazardous Materials, 80, 175-188. https://doi.org/10.1016/S0304-3894(00)00301-0

[2] Nameni, M., Moghadam, R.A. and Arami, M. (2008) Adsorption of Hexavalent Chromium from Aqueous Solutions by Wheat Bran. International Journal of Environmental Science and Technology, 5, 161-168. https://doi.org/10.1007/BF03326009

[3] Oguttu, H.W., Bugenyi, F.W., Leuenberger, H., Markus, W. and Bachofen, R. (2008) Polution Menacing Lake Victoria: Quantification of Point Sources around Jinja town, Uganda. Water $S A$, 34, 89-98. https://doi.org/10.4314/wsa.v34i1.180865

[4] United Nations Industrial Development Organistation (UNIDO) (2002) The Leather Sector in Uganda.

[5] Muwanga, A. and Barifaijo, E. (2006) Impact of Industrial Activities on Heavy Metal Loading and Their Physico-Chemical Effects on Wetlands of Lake Victoria Basin (Uganda). African Journal of Science and Technology, 7, 51-63. https://doi.org/10.4314/ajst.v7i1.55197

[6] Li, Q., Zhai, J., Zhang, W., Wang, M. and Zhou, J. (2007) Kinetic Studies of Adsorption of $\mathrm{Pb}(\mathrm{II}), \mathrm{Cr}(\mathrm{III})$ and $\mathrm{Cu}(\mathrm{II})$ from Aqueous Solution by Sawdust and Modified Peanut Husk. Journal of Hazardous Materials, 14, 163-167.

https://doi.org/10.1016/j.jhazmat.2006.06.109

[7] Verma, A., Chakraborty, S. and Basu, J.K. (2006) Adsorption Study of Hexavalent Chromium Using Tamarind Hull-Based Adsorbents. Separation and Purification Technology, 50, 336-341. https://doi.org/10.1016/j.seppur.2005.12.007 
[8] Lubanga, C., Ntambi, E. and Adaku, D. (2017) Potential of Artocarpus Heterophyllus Seed Powder in the Adsorption of Chromium (VI) from Aqueous Solution. Journal of Water Resource and Protection, 9, 614-628. https://doi.org/10.4236/jwarp.2017.96041

[9] APHA (2005) SM 3111B. Standard Methods for Examination of Water and Waste Water. Centennial Edition, American Public Health Association, Washington DC.

[10] Harris, D.C. (2007) Quantitative Chemical Analysis. W.H. Freeman and Company, USA.

[11] Skoog, D., West, D., Holler, F. and Crouch, S. (2004) Fundamentals of Analytical Chemistry. 8th Edition, Thomson Learning Academic Centre, USA

[12] Nechiporenko, G.N. (1958) Determination of Sulphate Ions by Titration with Lead Nitrate Using Dithizone as Indicator. Bulletin of the Academy of Sciences of the USSR, Division of Chemical Science, 7, 337-340. https://doi.org/10.1007/BF00913990

[13] Szabó, Z.G. and Barth, L. (1950) Titrimetric Determination of Nitrates with an Equivalent Ratio of 1:8. Nature, 166, 309. https://doi.org/10.1038/166309a0

[14] Baral, S.S., Das, S.N. and Rath, P. (2006) Hexavalent Chromium Removal from Aqueous by Adsorption on Treated Sawdust. Biochemical Engineering Journal, 13, 216-222. https://doi.org/10.1016/j.bej.2006.08.003

[15] Arshadi, M., Amiri, M.J. and Mousavi, S. (2014) Kinetic, Equilibrium and Thermodynamic Investoigations of $\mathrm{Ni}(\mathrm{II}), \mathrm{Cd}(\mathrm{II}), \mathrm{Cu}(\mathrm{II})$ and $\mathrm{Co}(\mathrm{II})$ Adsorption on Barley Straw Ash. Water Resources and Industry, 6, 1-17. https://doi.org/10.1016/j.wri.2014.06.001

[16] Mina. G., Hassan, H. and Maryam, M. (2011) Hexavalent Chromium Removal from Aqueous Solution via Adsorption on Granular Activated Carbon: Adsorption, Desorption, Modeling and Simulation Studies. ARPN Journal of Engineering and Applied Sciences, 6, 10-18.

[17] National Environment Management Authority (NEMA) (1999) The National Environment (Standards for Discharge of Effluent into Water and Land) Regulations.

[18] Friedl, S. (2003) What Is Eutrophication?-Definition, Causes and Effects. https://study.com/academy/lesson/what-is-eutrophication-definition-causes-effects. $\underline{\mathrm{html}}$

[19] Mohan, D., Pittman Jr., C.U., Bricka, M., Smith, F. and Yancey, B. (2007) Sorption of Arsenic, Cadmium and Lead by Chars Produced from Fast Pyrolysis of Wood and Bark During Bio-Oil Production. Journal of Colloid and Interface Science, 310, 57-73. https://doi.org/10.1016/j.jcis.2007.01.020

[20] Pandey, P.K, Sharma, S.K. and Sambi, S.S. (2010) Kinetics and Equilibrium Study of Chromium Adsorption on Zeolite $\mathrm{NaX}$. International Journal of Environmental Science and Technology, 7, 395-404. https://doi.org/10.1007/BF03326149

[21] Lakshmipathiraj, P., Umamaheswari, S., Bhaskar, R.G., Prabhakar, S., Caroling, G., Kato, S. and Kojima, T. (2011) Studies on Adsorption of Cr(VI) onto Strychnos potatorum Seed from Aqueous Solution. Environmental Progress \& Sustainable Energy, 32, 35-41. https://doi.org/10.1002/ep.10595

[22] Arivoli, S., Nandhakumar, V., Saravanan, S. and Sulochana, N. (2009) Adsorption Dynamics of Copper Ion by Low Cost Activated Carbon. The Arabian Journal for Science and Engineering, 34, 1-12.

[23] Argun, M.E., Dursun, S., Ozdemir, C. and Karatas, M. (2006) Heavy Metal Adsorption by Modified Oak Sawdust, Thermodynamics and Kinetics. Journal of Hazard- 
ous Materials, 141, 77-85. https://doi.org/10.1016/j.jhazmat.2006.06.095

[24] Langmuir, I. (1918) The Adsorption of Gases on Plane Surface of Glass, Mica and Platinum. Journal of the American Chemical Society, 40, 1361-1403.

https://doi.org/10.1021/ja02242a004

[25] Haghseresht, F. and Lu, G. (1998) Adsorption Chatacteristics of Phenolic Compounds onto Coal-Reject-Derived Adsorbents. Energy \& Fuels, 12, 1100-1107. https://doi.org/10.1021/ef9801165

[26] Bishnoi, N.R., Bajaj, M., Sharma, N. and Gupta, A. (2004) Adsorption of Cr(VI) on Activated Rice Husk Carbon and Activated Alumina. Bioresource Technology, 91, 305-307. https://doi.org/10.1016/S0960-8524(03)00204-9

[27] Oliveira, E.A., Montanher, S.F., Andrade, A.D., Nobrega, J.A. and Rollemberg, M.C. (2005) Equilibrium Studies for the Sorption of Chromium and Nickel from Aqueous Solutions Using Raw Rice Bran. Process Biochemistry, 40, 3485-3490.

https://doi.org/10.1016/j.procbio.2005.02.026 